\title{
Allele Frequency and Genotype Distribution of 9 SNPs in the Kazakh Population
}

\author{
Aisha N Iskakova ${ }^{1,2 *}$, Aliya A Romanova ${ }^{1,2}$, Elena N Voronina ${ }^{3}$, Nurgul S Sikhayeva ${ }^{1}$, Liliya A Belozerceva ${ }^{3}$, Maksim L Filipenko ${ }^{3}$ and Erlan M $^{2}$ \\ Ramanculov ${ }^{1}$ \\ ${ }^{1}$ National Centre for Biotechnology, Astana, Kazakhstan \\ ${ }^{2}$ General Genetics LLP, Astana, Kazakhstan \\ ${ }^{3}$ Institute of Chemical Biology and Fundamental Medicine, Siberian Branch of the Russian Academy of Sciences (RAS ICBFM), Novosibirsk, Russia
}

\begin{abstract}
Background: Determining the allelic variants of xenobiotic biotransformation genes is important, especially for prescribing personalised drugs. Knowledge of the allele distribution in different populations may be considered when selecting the preferred medication regimen. The frequency of CYP2C9, VKORC1, CYP4F2, GGCX, CYP2D6 and CYP1A2 genes has been studied in many populations, but the populations in Central Asia have not yet been investigated.
\end{abstract}

Methods and materials: Using real-time PCR and direct sequencing-based methods, the current study assessed the frequencies of 9 polymorphisms of genes encoding enzymes involved in drug metabolism in 450 healthy individuals from different regions of Kazakhstan and 575 healthy individuals from the West-Siberian region of Russia.

Results: The allele frequencies in the Kazakh population were determined for CYP2C9*2 $(0.02), C Y P 2 C 9^{*} 3(0.03)$, VKORC1 c. $173+1369 \mathrm{G}>\mathrm{C}$, VKORC1 c. $173+1000 \mathrm{C}>\mathrm{T}$ (0.72, CYP4F2 (0.31), GGCX (0.04), CYP2D6*4 (0.07), CYP2D6*3 $(0.01)$ and CYP1A2*1F (0.35). All alleles were in Hardy-Weinberg equilibrium $(p>0.05)$.

The allele frequencies in the Russian population were as follows: CYP2C9*2, 0.08; CYP2C9*3, 0.08; VKORC1 (c. 173+1000C>T), 0.40; VKORC1 (c. 173+1369G>C), 0.41; CYP4F2 (c. 1297G>A), 0.24; GGCX (c. 1913+45G>C), 0.08; CYP2D6*3, 0.15; CYP2D6*4, 0.22; and CYP1A2*1F (c. -9-154C>A), 0.31. All alleles were in Hardy-Weinberg equilibrium ( $p>0.05)$, except GGCX ( $p=0.04)$.

Conclusion: The Kazakh population allele frequency was between the Caucasian and Asian populations for nearly all of the studied gene allele variants.

Keywords: CYP2; VKORC1; GGCX; Allele frequency; Kazakh; Russian

\section{Introduction}

The use of pharmacological agents in the treatment of diseases is becoming increasingly important in modern medicine. However, considerable variability in the efficacy and side effects of medications between different population groups and different individuals is well known from medical practice. The risk of non-standard reactions has increased as result of the production of new medicines and the increasing number of medications taken by patients. Almost $50 \%$ of cases of adverse drug reactions or lack of therapy efficacy is caused by the genetic characteristics of a patient [1].

The action of drugs in the human body is due to processes such as absorption, distribution (by organs, cells, and organelles), interaction with receptors, metabolism and excretion.

All stages of the pharmacokinetic process are carried out by means of specific and non-specific enzymes, and xenobiotic biotransformation proteins play a major role in these processes. Mutations in the genes encoding these enzymes may lead to a decrease or increase of their enzymatic activity, which affects the metabolic rate of the corresponding drugs.

Direct (phenotypic) determination of the concentration change rate of a drug or its metabolites in the blood is a time-consuming and complicated procedure, in addition to requiring the patient to take the relevant medication. Determining allelic variants (genotype) of biotransformation genes, however, allows for the identification of patients who are more likely to develop adverse drug reactions.

\section{CYP2C9 gene}

The CYP2C9 gene has high genetic polymorphism. The structural gene polymorphisms CYP2C9 - R144C (CYP2C9*2) and I359L $\left(C Y P 2 C 9^{*} 3\right)$ are the most well-studied. The allele $C Y P 2 C 9^{*} 2$ reduces the warfarin dose by $40 \%$ for heterozygotes and $68 \%$ by homozygotes, and the CYP2C $9 * 3$ allele by 40 and $85 \%$, respectively. This polymorphic variant explained $14.5 \%$ of the interindividual variability in the dose of warfarin together with non-genetic predictors, such as age, body weight and height [2].

\section{VKORC1 gene}

The VKORC1 gene on chromosome 16 is one of the major genes associated with effective doses of coumarin anticoagulants. Many mutations are associated with a deficiency in this enzyme. The allelic variant $V K O R C 1$ c. $-1639 \mathrm{G}>\mathrm{A}$ determines up to $30 \%$ of the variability in warfarin dosage [3-8].

*Corresponding author: Aisha N Iskakova, National Centre for Biotechnology Valikhanov St 13/1, Astana, 010000, Kazakhstan, Tel: 007701 9521056; E-mail: aishaisk1@gmail.com

Received March 17, 2014; Accepted April 22, 2014; Published April 30, 2014

Citation: Iskakova AN, Romanova Voronina AA, Voronina EN, Sikhayeva NS Belozerceva AB, et al. (2014) Allele Frequency and Genotype Distribution of SNPs in the Kazakh Population. J Pharmacogenomics Pharmacoproteomics 5: 129. doi:10.4172/2153-0645.1000129

Copyright: @ 2014 Iskakova AN, et al. This is an open-access article distributed under the terms of the Creative Commons Attribution License, which permits unrestricted use, distribution, and reproduction in any medium, provided the original author and source are credited. 
Citation: Iskakova AN, Romanova Voronina AA, Voronina EN, Sikhayeva NS, Belozerceva AB, et al. (2014) Allele Frequency and Genotype Distribution of 9 SNPs in the Kazakh Population. J Pharmacogenomics Pharmacoproteomics 5: 129. doi:10.4172/2153-0645.1000129

Page 2 of 8

\section{CYP4F2 gene}

The CYP4F2 enzyme of the cytochrome P450 superfamily is responsible for the synthesis of hydroxyeicosatetraenoic acid (20HETE), which plays an important role in blood vessel function. Therefore, the production efficiency of 20-HETE may cause CYP4F2 to be associated with the warfarin dose. The CYP4F2 c. 1297G >A mutation, which leads to the V433M amino acid substitution, affects the activity of the enzyme, reducing 20-HETE synthesis to $60 \%$ [9]. In this case, the warfarin dosage should be increased.

\section{GGCX gene}

GGCX is a key factor in the regulation of blood clotting. Several mutations in the GGCX gene associated with a decrease in the clotting factor activity have been found. One of these mutations is rs11676382 c. $1913+45 \mathrm{G}>$ C, which was detected in intron 14 . A study of 186 Caucasians who took thrombosis therapy using warfarin showed that a polymorphic locus accounts for approximately $2 \%$ of the variation in drug dosage [10].

\section{CYP2D6 gene}

The CYP2D6 enzyme is encoded by a gene on chromosome 22 . Approximately $25 \%$ of all drugs are substrates of CYP2D6, including beta-blockers, tricyclic antidepressants, neuroleptics, derivatives of morphine and other drugs. At least 40 genetic variants of CYP2D6 can result in the reduced metabolic activity of this enzyme. However, the major variants of interest are the ${ }^{\star} 1-6,{ }^{*} 9,{ }^{\star} 10$ and ${ }^{\star} 17$ alleles. Carriers with the CYP2D6*3 and CYP2D6*4 alleles have no enzyme activity. For example, a $25 \%$ dose reduction is recommended with amitriptyline therapy and for $C Y P 2 D 6^{\star} 4$ allele carriers, therapy with other analgesics is recommended rather than using codeine [2].

\section{CYP1A2 gene}

The CYP1A subfamily in humans and other mammals consists of two enzymes; according to standard $\mathrm{P} 450$ nomenclature, they are denoted as CYP1A1 and CYP1A2. These enzymes have prompted significant interest because they are involved in the metabolic activation of many procarcinogens and are induced by compounds of interest to toxicology, including dioxins. More than 15 alleles of the CYP1A2 gene have been identified to date $\left({ }^{\star} 1 \mathrm{~B}^{*}{ }^{\star} 16\right)$, including several promoter variants [11].

The polymorphic variants g. $28338 \mathrm{G}>\mathrm{A}\left(\mathrm{CYP} 1 \mathrm{A2} 2^{\star} 1 \mathrm{C}\right)$, c.-1635delT $\left({ }^{*} 1 \mathrm{D}\right),-739 \mathrm{~T}>\mathrm{G}\left({ }^{*} 1 \mathrm{E}\right)$ and c. $-9-154 \mathrm{C}>\mathrm{A}\left({ }^{*} 1 \mathrm{~F}\right)$ located in intron 1 are the most thoroughly studied alleles that lead to a change in the enzymatic activity of CYP1A2. A polymorphic variant $C Y P 1 A 2{ }^{\star} 1 F$ (c.-9-154C>A) in intron 1 leads to increased enzyme inducibility and increased drug metabolism. For example, increased enzyme inducibility during smoking, leads to low concentrations of clozapine levels in schizophrenic patients undergoing standard treatment. The risk of toxicity increased in allele $\mathrm{C}$ carriers during leflunomide and olanzapine therapy [12].

Determining the allelic variants of xenobiotic biotransformation genes is not only important for personalised drug prescription; the knowledge of the allele frequency distribution in different populations may be taken into account when the preferred medication regimen is selected. The frequency of CYP2C9, VKORC1, CYP4F2, GGCX, CYP2D6, and CYP1A2 gene polymorphisms has been studied thoroughly in worldwide populations, except for populations in Central Asia (Tables 1 and 2).

Kazakhs are one of the Turkic peoples of Central Asia and comprise the majority of the population in Kazakhstan. According to the Agency of Statistics of the Republic of Kazakhstan, approximately 11 million Kazakhs live in Kazakhstan, and approximately 3.5 million Kazakhs live in regions neighbouring Kazakhstan and other regions (China, Russia, Uzbekistan, Turkmenistan, Kyrgyzstan, west Mongolia, Turkey) [13]. Kazakhs residing in the territory of Kazakhstan are internally divided into three large groups, the Elder, Middle and Lesser Zhuzes (or Hordes), which have historically demarcated territories. There are several tribes in each Zhuz [14]. Every Kazakh knows to which tribe and Zhuz they belong. Representatives of the same tribe are considered relatives because they

\begin{tabular}{|c|c|c|c|c|c|c|}
\hline Polymorphism & Allele variant & Amino acide change & Location & Position & Enzyme activity & NCBI dbSNP rs \\
\hline CYP2C9*2 & c. $430 \mathrm{C}>\mathrm{T}$ & $\mathrm{R} 144 \mathrm{C}$ & 10q23.33 & Exon 3 & decreased & rs1799853 \\
\hline CYP2C9*3 & c. $1075 \mathrm{~A}>\mathrm{C}$ & I359L & $10 q 23.33$ & Exon 7 & decreased & rs1057910 \\
\hline VKORC1 & c. $173+1000 \mathrm{C}>\mathrm{T}$ & & $16 p 11.2$ & Intron 1 & decreased & rs9934438 \\
\hline VKORC1 & c. $173+1369 \mathrm{G}>\mathrm{C}$ & & $16 p 11.2$ & Intron 2 & decreased & rs8050894 \\
\hline CYP4F2 & c. $1297 \mathrm{G}>\mathrm{A}$ & V433M & $19 p 13$ & Exon 2 & decreased & rs2108622 \\
\hline GGCX & c. $1913+45 G>C$ & & $2 \mathrm{p} 11.2$ & Intron & decreased & rs11676382 \\
\hline$C Y P 2 D 6 * 3$ & c. 622 delA & frameshift Arg208Glyfs & $22 q 13.2$ & Exon 5 & none & rs35742686 \\
\hline CYP2D6*4 & c. $353-1 \mathrm{G}>\mathrm{A}$ & splicing defect & $22 q 13.2$ & Intron 3 & none & rs3892097 \\
\hline CYP1A2*1F & c. $-9-154 C>A$ & promoter & $15 q 24.1$ & Intron & incresed & rs762551 \\
\hline
\end{tabular}

Table 1: Characteristic of studied allele variants of the CYP2C9, VKORC1, CYP4F2, GGCX, CYP2D6 and CYP1A2*1F genes.

\begin{tabular}{|c|c|c|c|}
\hline Allele & $x^{2}, p$ & $\varphi^{*}$ & Power \\
\hline CYP2C9*2 (C430T) & $X^{2}=28.562 ; p=0.000$ & 3.09 & 1 \\
\hline CYP2C9*3 (A1075C) & $X^{2}=19.817 ; p=0.000$ & 2.57 & 0.98 \\
\hline VKORC 1173 & $X^{2}=142.969 ; p=0.000$ & 6.90 & 1 \\
\hline VKORC 1542 & $x^{2}=138.415 ; p=0.000$ & 6.79 & 1 \\
\hline CYP4F2 & $x^{2}=6.615 ; p=0.037$ & 1.48 & 0.65 \\
\hline GGCX & $X^{2}=13.016 ; p=0.002$ & 2.08 & 0.90 \\
\hline$C Y P 2 D 6 * 3$ & $X^{2}=74.323 ; p=0.000$ & 4.98 & 1 \\
\hline$C Y P 2 D 6 * 4$ & $X^{2}=58.649 ; p=0.000$ & 4.42 & 1 \\
\hline CYP1A2*1F & $x^{2}=3.537 ; p=0.171$ & 1.09 & 0.38 \\
\hline
\end{tabular}

${ }^{*} \varphi$ - noncentrality parameter

Table 2: Evaluation of genotype frequency differences between the Kazakh and Russian populations. 
Citation: Iskakova AN, Romanova Voronina AA, Voronina EN, Sikhayeva NS, Belozerceva AB, et al. (2014) Allele Frequency and Genotype Distribution of 9 SNPs in the Kazakh Population. J Pharmacogenomics Pharmacoproteomics 5: 129. doi:10.4172/2153-0645.1000129

Page 3 of 8

are considered to be descended from a common ancestor. Marriages are expected to respect the "seven generations law", that is, marriage between members of the same tribe is only possible when 7 generations from a common ancestor separate the individuals.

The purpose of this study was to determine the frequency of the allelic variants of CYP2C9 (CYP2C9*2, CYP2C9*3), VKORC1 (c. $173+1000 \mathrm{C}>\mathrm{T}$, c. $173+1369 \mathrm{G}>\mathrm{C}$ ), $C Y P 4 F 2$ (c. $1297 \mathrm{G}>\mathrm{A}), \operatorname{GGCX}$ (c. $1913+45 \mathrm{G}>\mathrm{C}$ ), CYP2D6 (CYP2D6*3, CYP2D6*4) and CYP1A2*1F (c. -9-154C>A) in Kazakh populations from different regions of Kazakhstan and in Russian populations from the West-Siberian region compared with published frequency data of other populations. The results of allele frequencies obtained by real-time PCR (RT-PCR) and direct sequencing methods from individuals from different regions of Kazakhstan were compared. Because no significant differences were found between these samples, the samples from the three regions were combined. The resulting distributions of allele and genotype frequency in the Kazakh population were compared with the frequencies in a Russian population, which was used as a control group.

\section{Materials and Methods}

\section{Characteristics of the study populations}

Kazakh and Russian populations were included (Table 3). The first group included people of Kazakh nationality. Each volunteer filled

\begin{tabular}{|c|c|c|}
\hline & Kazakh & Russian \\
\hline Number of samples & 450 & 575 \\
\hline Sex (\% male/female) & $31 / 69$ & $65 / 35$ \\
\hline Mean age, years & $40.6 \pm 13.2$ & $33.5 \pm 11$ \\
\hline Mean weight, kg & $68 \pm 14$ & \\
\hline Mean height, cm & $167 \pm 8.9$ & \\
\hline Number of samples by regions: & & \\
North Kazakhstan & 161 & \\
North-East Kazakhstan & 176 & \\
South Kazakhstan & 113 & \\
West-Siberian & 91 & \\
\hline Number of samples by Zhuzes: & 266 & \\
Elder Zhuze & 93 & \\
Middle Zhuze & & \\
Lesser Zhuze & & \\
\hline
\end{tabular}

Table 3: Characteristics of the studied groups. out a questionnaire in which they indicated their nationality and the nationality of their parents and grandparents, in addition to standard personal data. The concept of "Zhety ata" exists in the traditions of the Kazakh people. It means that each Kazakh should know 7 generations of their ancestors. Even today, this tradition is strongly maintained. Therefore, by conducting this survey, we were able to trace the ancestors of the participants to nearly 7 generations. As mentioned above, data on the participants' ancestors to the 2nd generation were collected through the questionnaire. Additionally, a verbal survey of the volunteers was performed to establish the ethnicity their ancestors from the third to the seventh generation. When any ancestors were found to be of other (not Kazakh) ethnicity, blood samples of these volunteers were excluded from the study. In addition to ethnicity, tribal affiliations of volunteers were specified. Kazakhs residing in the territory of Kazakhstan have an internal division into three large groups, the Elder, Middle and Lesser Zhuzes, which have historically demarcated territories. There are several tribes in each Zhuz.

The study group included 450 healthy individuals of Kazakh nationality from different regions of Kazakhstan, and a written informed consent was obtained from all of the participants. The age of the participants ranged from 17 to 70 years (mean age, $40.6 \pm 13.2$ years) (Table 3). Venous blood samples $(5 \mathrm{ml}$ ) in tubes with EDTA were collected at clinical bases in the cities of Astana and Kokshetau (North Kazakhstan), Pavlodar (Northeast Kazakhstan) and Taraz (South Kazakhstan). DNA from blood was extracted by the salting-out method [15].

The second group was used as the control and included Russian residents of the West-Siberian region (the Novosibirsk and Kemerovo regions and the Altai Krai) who donated blood in the regional blood transfusion station and passed the standard medical examination but were not permanent donors. The age of the participants ranged from 18 to 55 years (mean age, $33.5 \pm 11$ years) (Table 3 ). DNA was extracted from venous blood using the phenol-chloroform method [16].

Ethical approval was received from the Ethics Committee of the National Centre for Biotechnology of the Republic of Kazakhstan, Astana, Kazakhstan (No. 10,14.02.2010).

\section{Genotyping}

Genotyping was performed using two methods: RT-PCR and

\begin{tabular}{|c|c|c|}
\hline Alleles & Primers sequence (5'- $\left.3^{\prime}\right)$ & Probe sequence \\
\hline \multirow[t]{2}{*}{ CYP2C9*2 } & ctgcggaattttgggatg & 5'- r6g - cattgaggaccgtgttcaag -bhq-3' \\
\hline & taaggtcagtgatatggagtaggg & 5'- fam - cattgaggactgtgttcaagag -bhq-3' \\
\hline \multirow[t]{2}{*}{ CYP2C9*3 } & caaatgccctacacagatgc & 5'- r6g - ccagagataccttgaccttctc -bhq-3' \\
\hline & gatactattaatttggggacttcg & 5'- fam - ccagagatacattgaccttctc -bhq-3' \\
\hline \multirow[t]{2}{*}{ VKORC 1173} & acctgggetatcctctgttc & 5'- fam - cctagtccaagagtcgatgatc -bhq-3' \\
\hline & gggaggatagggtcagtg & 5'- r6g - ctagtccaagggtcgatgatc -bhq-3' \\
\hline \multirow[t]{2}{*}{ VKORC1 1542} & tcagccccactccatacaatc & 5'- r6g - ctcatcacggagcgtcctg -bhq-3' \\
\hline & ccagttagttacctccccacatc & 5'- fam- ctcatcaccgagcgtcctg -bhq-3' \\
\hline \multirow[t]{2}{*}{ CYP4F2 } & tgcctcatcagtgttttcgg & 5'- r6g - caacccagctgtgtggcc -bhq-3' \\
\hline & ttgagggaggtgatgttggatac & 5'- fam - caacccagctatgtggccg -bhq-3' \\
\hline \multirow[t]{2}{*}{ GGCX } & tatgtctttcgccgcaggt & 5'- r6g - tgttggcaagcttggtaact-bhq-3' \\
\hline & gaagaatggcaggaaaagatac & 5'- fam - tgttggcaaccttggtaact-bhq-3' \\
\hline \multirow[t]{2}{*}{$C Y P 2 D 6 * 3$} & tggcaatgtcctacgcttc & 5'- fam - tgagcacaggatgacct -bhq-3' \\
\hline & ctctcaccttctccatctctgc & 5'- r6g - tgagcacggatgacct -bhq-3' \\
\hline \multirow[t]{2}{*}{$C Y P 2 D 6 * 4$} & ggcaagaagtcgctggaccag & 5'- r6g- cccccaggacgcccct-bhq-3' \\
\hline & ttgctcacggetttgtccagg & 5'- fam- cccccaagacgcccctt-bhq-3' \\
\hline \multirow[t]{2}{*}{ CYP1A2*1F } & attctgtgatgctcaaagggtg & 5'- fam - ctgtgggcacaggacgca -bhq-3' \\
\hline & aaggagggactaggctgagg & 5'-r6g - ctgtgggcccaggacgc -bhq-3' \\
\hline
\end{tabular}

Table 4: Primers and probes using for genotyping by real-time PCR. 
Citation: Iskakova AN, Romanova Voronina AA, Voronina EN, Sikhayeva NS, Belozerceva AB, et al. (2014) Allele Frequency and Genotype Distribution of 9 SNPs in the Kazakh Population. J Pharmacogenomics Pharmacoproteomics 5: 129. doi:10.4172/2153-0645.1000129

Page 4 of 8

direct sequencing. The characteristics of the studied allele variants of the CYP2C9, VKORC1, CYP4F2, GGCX, CYP2D6 and CYP1A2*1F genes are shown in Table 1. A small amount of DNA was genotyped by direct sequencing and RT-PCR. Thus, the obtained DNA sample genotypes were used as a control for the further genotyping by RTPCR. DNA samples were genotyped by direct sequencing if genotype determination by RT-PCR was difficult.

\section{Genotyping by RT-PCR}

RT-PCR genotyping was performed using TaqMan probes (Table 4). The composition of the PCR mixture was as follows: a buffer (65

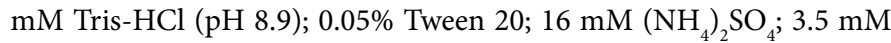
$\mathrm{MgCl}_{2}$ ), 0.1-0.2 $\mu \mathrm{M}$ Taqman probe with FAM, 0.1-0.2 $\mu \mathrm{M}$ Taqman probe with R6G, $0.2 \mathrm{mM}$ dNTPs, $0.3 \mu \mathrm{M}$ primers and 0.5 units of thermally stable Taq polymerase. The reaction volume was $25.5 \mu \mathrm{l}$, and each reaction mixture was covered by an equal volume of mineral oil. The PCR conditions were as follows: denaturation at $96^{\circ} \mathrm{C}$ for $2 \mathrm{~min}$ and then 45 two-step cycles, which included $96^{\circ} \mathrm{C}$ for $30 \mathrm{~s}, 58-60^{\circ} \mathrm{C}$ for 40

\begin{tabular}{|c|c|}
\hline Alleles & Primers sequence $\left(5^{\prime}-3^{\prime}\right)$ \\
\hline CYP2C9*2 & $\begin{array}{l}\text { tagtttcgtttctcttcctgtta } \\
\text { aaatgtttccaagaatgtcagta }\end{array}$ \\
\hline CYP2C9*3 & $\begin{array}{l}\text { ctaaagtccaggaagagattga } \\
\text { atgatactatgaatttggggact }\end{array}$ \\
\hline CYP4F2 & $\begin{array}{l}\text { agcggataacgtgttttcggaacccatcac } \\
\text { agcggataacgccttggaatggacaaaaac }\end{array}$ \\
\hline GGCX & $\begin{array}{l}\text { gcttcttgttgcgaaagctctat } \\
\text { caaacacttgggaacagttagct }\end{array}$ \\
\hline$C Y P 2 D 6 * 3$ & $\begin{array}{l}\text { cccgttctgtctggtgta } \\
\text { tgtcccagcaaagttcat }\end{array}$ \\
\hline CYP2D6*4 & $\begin{array}{l}\text { cttctccgtgtccacctt } \\
\text { ccttcttacagtggggtct }\end{array}$ \\
\hline
\end{tabular}

Table 5: The primers used to determine the nucleotide sequence by direct sequencing method. $\mathrm{s}$ and $25^{\circ} \mathrm{C}$ for $10 \mathrm{~s}$. The amplification was performed using the iCycler iQ5 PCR machine (Bio-Rad, United States).

\section{Genotyping by the direct sequencing method}

Fragments of the gene region containing the analysed SNPs were obtained by PCR using oligonucleotide pairs of primers (Table 5). The amplification was performed in a multichannel thermocycler "PTC0240 DNA EngineTetrad2 Cycler” (BioRad, Foster city, California, USA). The composition of the PCR mixture was as follows: a buffer (65

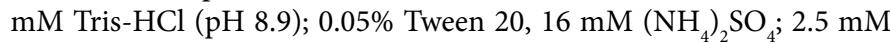
$\mathrm{MgCl}_{2}$ ), $0.2 \mathrm{mM}$ dNTPs, $0.4 \mu \mathrm{M}$ primers and 0.5 units of thermostable Taq-polymerase. The reaction volume was $25 \mathrm{ml}$. The PCR conditions were as follows: initial denaturation for $5 \mathrm{~min}$ at $95^{\circ} \mathrm{C}$ and then 35 cycles of three steps, 30 seconds of denaturation at $95^{\circ} \mathrm{C}, 30$ seconds of primer annealing at $50-60^{\circ} \mathrm{C}$ and 30 seconds elongation at $72^{\circ} \mathrm{C}$, and then $7 \mathrm{~min}$ at $72^{\circ} \mathrm{C}$. The identification of SNPs was carried out based on DNA sequencing using the Big Dye Terminanor v3.1 Cycle Sequencing Kit (3730XL Genetic Analyzer, Applied Biosystems ABI) in accordance with the manufacturer's protocol. Sequence Scanner v1.0 software was used for analysing data.

\section{Statistical analyses}

The statistical analysis was performed using SPSS software (v16.0). The correspondence of the distribution of the genotype frequencies to the Hardy-Weinberg equilibrium was assessed using the $\chi^{2}$ criterion $(\alpha=0.05, \mathrm{df}=2)$. Significant differences in genotype frequencies between Kazakh and Russian populations were assessed according to the $\chi^{2}$ criterion $(\alpha=0.05, \mathrm{df}=2)$. The analysis of linkage disequilibrium of genes VKORC1, CYP2C9, and CYP2D6 was performed using the available program at http://www.oege.org/software/cubex.

\section{Results}

Allele and genotype frequency data were obtained for 9 SNPs in

\begin{tabular}{|c|c|c|c|c|c|c|c|c|}
\hline Polymorphisms & $\begin{array}{l}\text { Number of } \\
\text { samples }\end{array}$ & $\begin{array}{c}\text { Hardy - Weinberg } \\
\text { equilibrium }\end{array}$ & Allele & $n^{a}$ & Frequency & Genotype & $\mathbf{n}^{\mathrm{b}}$ & Frequency \\
\hline CYP2C9*2 & 437 & $p=0.66$ & $\begin{array}{l}\mathrm{C} \\
\mathrm{T}\end{array}$ & $\begin{array}{c}856 \\
18\end{array}$ & $\begin{array}{l}0.98 \\
0.02\end{array}$ & $\begin{array}{l}\text { CC } \\
\text { CT } \\
\text { TT }\end{array}$ & $\begin{array}{c}419 \\
18 \\
0\end{array}$ & $\begin{array}{l}0.96 \\
0.04 \\
0.00\end{array}$ \\
\hline CYP2C9*3 & 444 & $p=0.54$ & $\begin{array}{l}A \\
C\end{array}$ & $\begin{array}{c}863 \\
25\end{array}$ & $\begin{array}{l}0.97 \\
0.03\end{array}$ & $\begin{array}{l}\text { AA } \\
A C \\
C C\end{array}$ & $\begin{array}{c}419 \\
25 \\
0\end{array}$ & $\begin{array}{l}0.94 \\
0.06 \\
0.00\end{array}$ \\
\hline VKORC1 1173 & 286 & $p=0.76$ & $\begin{array}{l}\mathrm{C} \\
\mathrm{T}\end{array}$ & $\begin{array}{l}162 \\
410\end{array}$ & $\begin{array}{l}0.28 \\
0.72\end{array}$ & $\begin{array}{l}\text { CC } \\
\text { CT } \\
\text { TT }\end{array}$ & $\begin{array}{c}24 \\
114 \\
148 \\
\end{array}$ & $\begin{array}{l}0.08 \\
0.40 \\
0.52\end{array}$ \\
\hline VKORC1 1542 & 259 & $p=0.65$ & $\begin{array}{l}\mathrm{G} \\
\mathrm{C}\end{array}$ & $\begin{array}{l}142 \\
376\end{array}$ & $\begin{array}{l}0.28 \\
0.72\end{array}$ & $\begin{array}{l}\text { GG } \\
\text { GC } \\
\text { CC }\end{array}$ & $\begin{array}{c}18 \\
106 \\
135\end{array}$ & $\begin{array}{l}0.07 \\
0.41 \\
0.52 \\
\end{array}$ \\
\hline CYP4F2 & 284 & $p=0.26$ & $\begin{array}{l}\mathrm{G} \\
\mathrm{A}\end{array}$ & $\begin{array}{l}396 \\
172\end{array}$ & $\begin{array}{l}0.70 \\
0.31\end{array}$ & $\begin{array}{l}\text { GG } \\
\text { GA } \\
\text { AA }\end{array}$ & $\begin{array}{c}134 \\
128 \\
22\end{array}$ & $\begin{array}{l}0.47 \\
0.45 \\
0.08\end{array}$ \\
\hline GGCX & 266 & $p=0.57$ & $\begin{array}{l}C \\
G\end{array}$ & $\begin{array}{c}514 \\
18\end{array}$ & $\begin{array}{l}0.97 \\
0.04\end{array}$ & $\begin{array}{l}\text { CC } \\
\text { CG } \\
\text { GG }\end{array}$ & $\begin{array}{c}248 \\
18 \\
0\end{array}$ & $\begin{array}{l}0.93 \\
0.07 \\
0.00\end{array}$ \\
\hline CYP2D6*3 & 287 & $p=0.86$ & $\begin{array}{c}\text { A } \\
\text { del }\end{array}$ & $\begin{array}{c}568 \\
6\end{array}$ & $\begin{array}{l}0.99 \\
0.01\end{array}$ & $\begin{array}{c}\text { AA } \\
\text { A/del } \\
\text { del/del }\end{array}$ & $\begin{array}{c}281 \\
6 \\
0\end{array}$ & $\begin{array}{l}0.98 \\
0.02 \\
0.00\end{array}$ \\
\hline CYP2D6*4 & 343 & $p=0.15$ & $\begin{array}{l}\mathrm{G} \\
\mathrm{A}\end{array}$ & $\begin{array}{c}637 \\
49\end{array}$ & $\begin{array}{l}0.93 \\
0.07\end{array}$ & $\begin{array}{l}\text { GG } \\
\text { GA } \\
\mathrm{AA}\end{array}$ & $\begin{array}{c}294 \\
49 \\
0\end{array}$ & $\begin{array}{l}0.86 \\
0.14 \\
0.00\end{array}$ \\
\hline CYP1A2*1F & 257 & $p=0.63$ & $\begin{array}{l}A \\
C\end{array}$ & $\begin{array}{l}332 \\
182\end{array}$ & $\begin{array}{l}0.65 \\
0.35\end{array}$ & $\begin{array}{l}\text { AA } \\
A C \\
C C\end{array}$ & $\begin{array}{c}109 \\
114 \\
34\end{array}$ & $\begin{array}{l}0.42 \\
0.44 \\
0.13\end{array}$ \\
\hline
\end{tabular}

anumber of chromosomes; ${ }^{\text {nnumber of alleles }}$

Table 6: Allele frequency and genotype distribution in the Kazakh population 
Citation: Iskakova AN, Romanova Voronina AA, Voronina EN, Sikhayeva NS, Belozerceva AB, et al. (2014) Allele Frequency and Genotype Distribution of 9 SNPs in the Kazakh Population. J Pharmacogenomics Pharmacoproteomics 5: 129. doi:10.4172/2153-0645.1000129

Page 5 of 8

the Kazakh and Russian populations. The allele frequencies (MAF) in the Kazakh population were as follows: $C Y P 2 C 9^{\star} 2,0.02$; $C Y P 2 C 9^{\star} 3,0.03$; VKORC1 (c. $173+1000 \mathrm{C}>\mathrm{T}$ ), 0.72; VKORC1 (c. 173+1369G>C), 0.72; CYP4F2 (c. 1297G>A), 0.31; GGCX (c. 1913+45G>C), 0.04; CYP2D6*3, $0.01 ; C Y P 2 D 6^{\star} 4,0.07$; and $C Y P 1 A 2^{\star} 1 F$ (c. $\left.-9-154 \mathrm{C}>\mathrm{A}\right), 0.35$. The allele and genotype frequencies of the Kazakh population are summarised in Table 6. All alleles were in Hardy-Weinberg equilibrium ( $>00.05$ ). DNA samples from individuals of Kazakh nationality were collected from different regions of Kazakhstan. Therefore, a comparative analysis of allele frequencies by regions using the statistical criterion $\chi^{2}$ was assessed. Significant differences in the Kazakh population according to region (North, Northeast and South Kazakhstan) are presented in Table 7. A significant difference in the frequency of genotypes was not found ( $p>0.05)$. Thus, the DNA samples from different regions of Kazakhstan were combined into one group.

DNA samples from a Russian population were used as the control. The allele frequencies (MAF) in the Russian population were as follows: CYP2C9 ${ }^{\star}$ 2, 0.08; CYP2C9 ${ }^{\star} 3,0.08 ; \operatorname{VKORC1~(c.~} 173+1000 \mathrm{C}>\mathrm{T}$ ), 0.40; VKORC1 (c. 173+1369G>C), 0.41; CYP4F2 (c. 1297G>A), 0.24; GGCX (c. $1913+45 \mathrm{G}>\mathrm{C}$ ), $0.08 ; C Y P 2 D 6^{\star} 3,0.15 ; C Y P 2 D 6^{\star} 4,0.22$; and $C Y P 1 A 2^{\star} 1 F$ (c. $-9-154 \mathrm{C}>\mathrm{A}$ ), 0.31 . The allele and genotype frequencies of the Russian population are summarised in Table 8. All alleles except GGCX $(\mathrm{p}=0.04)$ were in Hardy-Weinberg equilibrium ( $p>0.05$ ) in the Russian population.

\begin{tabular}{|c|c|c|c|c|}
\hline \multirow[b]{2}{*}{ Allele } & \multicolumn{3}{|c|}{ Allele frequency } & \multirow[b]{2}{*}{ Significant differences } \\
\hline & $\begin{array}{c}\text { North } \\
\text { Kazakhstan } n=72\end{array}$ & $\begin{array}{c}\text { North-east } \\
\text { Kazakhstan } n=146\end{array}$ & South Kazakhstan $n=70$ & \\
\hline CYP2C9*2 (C430T) & $\begin{array}{l}\mathrm{C}=0.94 \\
\mathrm{~T}=0.06\end{array}$ & $\begin{array}{l}\mathrm{C}=0.98 \\
\mathrm{~T}=0.02\end{array}$ & $\begin{array}{l}\mathrm{C}=0.97 \\
\mathrm{~T}=0.03\end{array}$ & $x^{2}=3.982 ; p=0.137$ \\
\hline CYP2C9*3 (A1075C) & $\begin{array}{l}A=0.96 \\
C=0.04\end{array}$ & $\begin{array}{l}A=0.95 \\
C=0.05\end{array}$ & $\begin{array}{l}A=0.96 \\
C=0.04\end{array}$ & $x^{2}=0.427 ; p=0.808$ \\
\hline VKORC 1173 & $\begin{array}{l}\mathrm{C}=0.31 \\
\mathrm{~T}=0.69\end{array}$ & $\begin{array}{l}\mathrm{C}=0.27 \\
\mathrm{~T}=0.73\end{array}$ & $\begin{array}{l}\mathrm{C}=0.28 \\
\mathrm{~T}=0.72\end{array}$ & $x^{2}=4.007 ; p=0.405$ \\
\hline VKORC 1542 & $\begin{array}{l}G=0.29 \\
C=0.71\end{array}$ & $\begin{array}{l}G=0.27 \\
C=0.73\end{array}$ & $\begin{array}{l}G=0.26 \\
C=0.74\end{array}$ & $x^{2}=0.701 ; p=0.951$ \\
\hline CYP4F2 & $\begin{array}{l}G=0.64 \\
A=0.36\end{array}$ & $\begin{array}{l}G=0.72 \\
A=0.28\end{array}$ & $\begin{array}{l}G=0.73 \\
A=0.27\end{array}$ & $x^{2}=6.175 ; p=0.186$ \\
\hline GGCX & $\begin{array}{l}C=0.95 \\
G=0.05\end{array}$ & $\begin{array}{l}C=0.97 \\
G=0.03\end{array}$ & $\begin{array}{l}C=0.98 \\
G=0.02\end{array}$ & $X^{2}=0.968 ; p=0.616$ \\
\hline$C Y P 2 D 6^{*} 3$ & $\begin{array}{c}A=0.99 \\
\text { del }=0.01\end{array}$ & $\begin{array}{c}A=0.99 \\
\text { del }=0.01\end{array}$ & $\begin{array}{c}A=1.00 \\
\text { del }=0.00\end{array}$ & $x^{2}=1.940 ; p=0.379$ \\
\hline$C Y P 2 D 6 * 4$ & $\begin{array}{l}G=0.94 \\
A=0.06\end{array}$ & $\begin{array}{l}G=0.90 \\
A=0.10\end{array}$ & $\begin{array}{l}G=0.91 \\
A=0.09\end{array}$ & $x^{2}=2.417 ; p=0.299$ \\
\hline CYP1A2*1F & $\begin{array}{l}A=0.63 \\
C=0.38\end{array}$ & $\begin{array}{l}A=0.63 \\
C=0.37\end{array}$ & $\begin{array}{l}A=0.69 \\
C=0.31\end{array}$ & $x^{2}=5.710 ; p=0.222$ \\
\hline
\end{tabular}

Table 7: Evaluation of allele and genotype frequency differences according to region (North, Northeast and South Kazakhstan).

\begin{tabular}{|c|c|c|c|c|c|c|c|c|}
\hline Polymorphisms & Number of samples & $\begin{array}{l}\text { Hardy - Weinberg } \\
\text { equilibrium }\end{array}$ & Allele & $n^{a}$ & Frequency & Genotype & $n^{b}$ & Frequency \\
\hline CYP2C9*2 & 284 & $p=0.11$ & $\begin{array}{l}\mathrm{C} \\
\mathrm{T}\end{array}$ & $\begin{array}{c}521 \\
47\end{array}$ & $\begin{array}{l}0.92 \\
0.08\end{array}$ & $\begin{array}{l}\text { CC } \\
\text { CT } \\
\text { TT }\end{array}$ & $\begin{array}{c}241 \\
39 \\
4\end{array}$ & $\begin{array}{l}0.85 \\
0.14 \\
0.01\end{array}$ \\
\hline CYP2C9*3 & 283 & $p=0.86$ & $\begin{array}{l}A \\
C\end{array}$ & $\begin{array}{c}521 \\
45\end{array}$ & $\begin{array}{l}0.92 \\
0.08\end{array}$ & $\begin{array}{l}\text { AA } \\
\text { AC } \\
\text { CC }\end{array}$ & $\begin{array}{c}240 \\
41 \\
2\end{array}$ & $\begin{array}{l}0.85 \\
0.14 \\
0.01\end{array}$ \\
\hline VKORC1 1173 & 575 & $p=0.73$ & $\begin{array}{l}\mathrm{C} \\
\mathrm{T}\end{array}$ & $\begin{array}{l}685 \\
465\end{array}$ & $\begin{array}{l}0.60 \\
0.40\end{array}$ & $\begin{array}{l}\text { CC } \\
\text { CT } \\
\text { TT }\end{array}$ & $\begin{array}{c}202 \\
281 \\
92\end{array}$ & $\begin{array}{l}0.35 \\
0.49 \\
0.16\end{array}$ \\
\hline VKORC1 1542 & 574 & $p=0.53$ & $\begin{array}{l}\mathrm{G} \\
\mathrm{C}\end{array}$ & $\begin{array}{l}677 \\
471\end{array}$ & $\begin{array}{l}0.59 \\
0.41\end{array}$ & $\begin{array}{l}\text { GG } \\
\text { GC } \\
\text { CC }\end{array}$ & $\begin{array}{c}196 \\
285 \\
93\end{array}$ & $\begin{array}{l}0.34 \\
0.50 \\
0.16\end{array}$ \\
\hline CYP4F2 & 284 & $p=0.73$ & $\begin{array}{l}\mathrm{G} \\
\mathrm{A}\end{array}$ & $\begin{array}{l}433 \\
135\end{array}$ & $\begin{array}{l}0.76 \\
0.24\end{array}$ & $\begin{array}{l}\text { GG } \\
\text { GA } \\
\text { AA }\end{array}$ & $\begin{array}{c}164 \\
105 \\
15\end{array}$ & $\begin{array}{l}0.58 \\
0.37 \\
0.05\end{array}$ \\
\hline GGCX & 565 & $p=0.04$ & $\begin{array}{l}\mathrm{C} \\
\mathrm{G}\end{array}$ & $\begin{array}{c}1041 \\
89\end{array}$ & $\begin{array}{l}0.92 \\
0.08\end{array}$ & $\begin{array}{l}\text { CC } \\
\text { CG } \\
\text { GG }\end{array}$ & $\begin{array}{c}476 \\
89 \\
0\end{array}$ & $\begin{array}{l}0.84 \\
0.16 \\
0.00\end{array}$ \\
\hline CYP2D6*3 & 350 & $p=0.59$ & $\begin{array}{c}\text { A } \\
\text { del }\end{array}$ & $\begin{array}{l}596 \\
104\end{array}$ & $\begin{array}{l}0.85 \\
0.15\end{array}$ & $\begin{array}{c}\text { AA } \\
\text { A/del } \\
\text { del/del }\end{array}$ & $\begin{array}{c}255 \\
86 \\
9\end{array}$ & $\begin{array}{l}0.73 \\
0.25 \\
0.03\end{array}$ \\
\hline CYP2D6*4 & 352 & $p=0.84$ & $\begin{array}{l}\mathrm{G} \\
\mathrm{A}\end{array}$ & $\begin{array}{l}551 \\
153\end{array}$ & $\begin{array}{l}0.78 \\
0.22\end{array}$ & $\begin{array}{l}\text { GG } \\
\text { GA } \\
\text { AA }\end{array}$ & $\begin{array}{c}215 \\
121 \\
16\end{array}$ & $\begin{array}{l}0.61 \\
0.34 \\
0.05\end{array}$ \\
\hline CYP1A2*1F & 341 & $p=0.25$ & $\begin{array}{l}A \\
C\end{array}$ & $\begin{array}{l}468 \\
214\end{array}$ & $\begin{array}{l}0.69 \\
0.31\end{array}$ & $\begin{array}{l}\text { AA } \\
\text { AC } \\
\text { CC }\end{array}$ & $\begin{array}{c}156 \\
156 \\
29\end{array}$ & $\begin{array}{l}0.46 \\
0.46 \\
0.09\end{array}$ \\
\hline
\end{tabular}

anumber of chromosomes; ${ }^{b}$ number of alleles

Table 8: Allele frequency and genotype distribution in the Russian population. 
Citation: Iskakova AN, Romanova Voronina AA, Voronina EN, Sikhayeva NS, Belozerceva AB, et al. (2014) Allele Frequency and Genotype Distribution of 9 SNPs in the Kazakh Population. J Pharmacogenomics Pharmacoproteomics 5: 129. doi:10.4172/2153-0645.1000129

Page 6 of 8

\begin{tabular}{|c|c|c|c|}
\hline LD & VKORC1 1542 & CYP2C9*2 & CYP2D6*3 \\
\hline VKORC1 1173 & $\begin{array}{c}\mathrm{D}^{\prime}=0.96 \\
\mathrm{r}^{2}=0.9094\end{array}$ & \\
\hline CYP2C9*3 & & $\begin{array}{r}\mathrm{D}^{\prime}=-1.0 \\
\mathrm{r}^{2}=0.0006\end{array}$ & \\
\hline CYP2D6*4 & & & $\begin{array}{r}\mathrm{D}^{\prime}=-1.0 \\
\mathrm{r}^{2}=0.001\end{array}$ \\
\hline
\end{tabular}

Table 9: Evaluation of linkage disequilibrium of the VKORC1, CYP2C9 and CYP2D6 genes in the Kazakh population.

Significant differences in genotype frequencies between Kazakh and Russian populations were assessed according to the $\chi^{2}$ criterion. The overall difference (between Kazakh and Russian populations) in allele frequencies were highly significant $(\mathrm{p}<0.05)$, except for $C Y P 1 A 2^{\star} 1 F(\mathrm{p}=0.17)$ (Table 2).

Furthermore, the linkage disequilibrium of the VKORC1, CYP2C9 and CYP2D6 genes in the Kazakh population was analysed. We identified the linkage disequilibrium of the VKORC1 c. 173+1369G >C and $V K O R C 1$ c. $173+1000 \mathrm{C}>\mathrm{T}\left(\mathrm{D}^{\prime}=0.96\right)$ allele polymorphisms (Table 9).

\section{Discussion}

Kazakhs residing in Kazakhstan are internally divided into three large groups, the Elder, Middle and Lesser Zhuzes, which have historically demarcated territories. There are several tribes in each Zhuz.

The metabolism of xenobiotics may vary depending on the individual's ethnicity and race. Therefore, we compared allele frequencies from the different regions of Kazakhstan. Blood samples were collected from the northern and southern part of Kazakhstan because the climatic conditions differ from north to south. Northern and Northeastern Kazakhstan are traditionally the territory of the Middle Zhuze, and Southern Kazakhstan is traditionally the territory of the Elder Zhuze. However, significant differences between genotype frequencies were not detected $(p>0.05)$ (Table 7).

Tribes within Zhuzes are considered related to each other, and marriage between Zhuzes is encouraged. Therefore, the distribution of allele frequencies between all three Zhuzes was nearly equal, which allowed the DNA samples from different regions of Kazakhstan to be combined into one group, representative of the Kazakh population.

The previous literature has examined Kazakh populations living in areas other than those included here. For example, Wang et al. studied Kazakhs living in China [17]; ethnicity was only tracked until the third generation. Thus, we could not use these data to assess differences. Magalon et al. studied only 26 DNA samples and did not indicate whether they monitored the ethnicity of the participants' ancestors, which does not allow an adequate comparative analysis [18]. Tarlykov et al. investigated the hypervariable segment I of mitochondrial DNA and Y-STR loci in DNA samples of individuals living in isolation in the same area and who were members of the same tribe. However, there was no comparative analysis with other groups living in other regions of Kazakhstan or who were representatives of other tribes and Zhuzes [19].

A Russian population was used as a control group. A comparative analysis of the allele frequency of the Russian population between the studied samples and published data was carried out. The findings correspond to published data (Table 10).

Furthermore, a comparative analysis of the allele frequency of the Kazakh population between studied samples and published data from the other populations was conducted (Table 10).

\section{CYP2C9 gene}

Wide inter-ethnic variability was observed for the CYP2C9 gene polymorphic variants. On average, the frequency of the CYP2C $9^{*} 2$ allele was $11-15 \%$ in the Caucasian population and $2-3 \%$ in the African and Asian populations, and for the $\mathrm{CYP}_{2} \mathrm{C}^{*} 3$ allele, the averages were $5-7 \%$ and $2-4 \%$, respectively $[3,4,20]$. Thus, the ${ }^{\star} 2$ and ${ }^{\star} 3$ alleles of the CYP2C9 gene are much less common among individuals in Asia and Africa than among Caucasians.

The allele frequency of $C Y P 2 C 9^{*} 2(0.02)$ and $C Y P 2 C 9^{* 3}(0.03)$ in the Kazakh population is near the frequency of these polymorphic loci in Asian populations $(\mathrm{p}=0.27$ and $\mathrm{p}=0.30)$ and significantly different from that of Caucasian populations $(\mathrm{p}=0.00)$.

In the Russian population, the frequency of $C Y P 2 C 9^{*} 3(0.08)$ is close to that of the Caucasian population $(\mathrm{p}=0.45)$ and significantly different from the frequency in the Asian and African-American populations $(\mathrm{p}=0.00)$.

Thus, in future pharmacogenetic studies in Kazakh populations, close attention should be paid to the polymorphic variants of the CYP2C9 gene, which affect the dose of warfarin and are characteristic of Asian populations.

\section{VKORC1 gene}

The distribution of $V K O R C 1$ allele polymorphisms in populations is interesting. The C. $173+1000 \mathrm{C}>\mathrm{T}$ allele frequency is as high as $92 \%$ in Asian populations [4], whereas in Caucasian populations, it is approximately $42 \%$ [5]. The allele frequency in the Kazakh population $(\mathrm{f}=0.72, \mathrm{p}=0.00)$ studied here was between that of Asian and Caucasian populations.

The allele frequency in the Russian population was $0.41(\mathrm{p}=0.09)$, which agrees with published data and corresponds to the Caucasoid populations.

According to Rieder et al., the VKORC1 c.-1639G $>$ A mutation is linked to mutations in $V K O R C 1$ c. $173+1369 \mathrm{G}>\mathrm{C}$ and $V K O R C 1 \mathrm{c}$.

\begin{tabular}{|c|c|c|c|c|c|c|c|c|c|}
\hline & $2 c 9 * 2$ & $2 c 9 * 3$ & VKORC rs9934438 & VKORC rs8050894 & CYP4F2 & GGCX & $2 \mathrm{~d} 6 * 3$ & $2 \mathrm{~d} 6 * 4$ & $1 \mathrm{a} 2 * 1 \mathrm{~F}$ \\
\hline Kazakh & 0.02 & 0.03 & 0.72 & 0.72 & 0.31 & 0.04 & 0.01 & 0.07 & 0.35 \\
\hline Russian & 0.08 & 0.08 & 0.40 & 0.41 & 0.24 & 0.08 & 0.15 & 0.22 & 0.31 \\
\hline $\begin{array}{c}\text { African-American (1000 } \\
\text { Genomes) }\end{array}$ & 0.02 & 0.01 & 0.07 & 0.21 & 0.09 & 0.01 & 0.0 & 0.06 & 0.46 \\
\hline African-American ${ }^{\star}$ & $0.01-0.027$ & $0.005-0.02$ & $0.02-0.13$ & $0.19-0.28$ & $0.05-0.1$ & $0.0-0.02$ & $0.0-0.01$ & $0.01-0.12$ & $0.35-0.54$ \\
\hline Caucasians (1000 Genomes) & 0.12 & 0.06 & 0.4 & 0.41 & 0.27 & 0.09 & 0.02 & 0.19 & 0.31 \\
\hline Caucasians* & $0.11-0.2$ & $0.06-0.16$ & $0.39-0.48$ & $0.37-0.41$ & $0.23-0.32$ & $0.05-0.13$ & $0.0-0.04$ & $0.07-0.21$ & $0.22-0.52$ \\
\hline Asians (1000 Genomes) & 0.0 & 0.02 & 0.92 & 0.92 & 0.21 & 0.0 & 0.0 & 0.0 & 0.37 \\
\hline Asians $^{*}$ & $0.0-0.05$ & $0.02-0.1$ & $0.9-0.95$ & $0.89-0.94$ & $0.19-0.34$ & 0.0 & 0.0 & $0.0-0.15$ & $0.33-0.61$ \\
\hline
\end{tabular}

*Different sources with a population sample of more than 100 people (including HapMap data) [3-8,10-12,20-48].

Table 10: A comparative table of frequencies of genes in different populations. 
Citation: Iskakova AN, Romanova Voronina AA, Voronina EN, Sikhayeva NS, Belozerceva AB, et al. (2014) Allele Frequency and Genotype Distribution of 9 SNPs in the Kazakh Population. J Pharmacogenomics Pharmacoproteomics 5: 129. doi:10.4172/2153-0645.1000129

Page 7 of 8

$173+1000 \mathrm{C}>\mathrm{T}[6]$. We also identified a linkage disequilibrium between the VKORC1 c. $173+1369 \mathrm{G}>\mathrm{C}$ and $V K O R C 1$ c. $173+1000 \mathrm{C}>\mathrm{T}\left(\mathrm{D}^{\prime}=0.96\right)$ polymorphisms (Table 9).

\section{CYP4F2 gene}

The CYP4F2 c. $1297 \mathrm{G}>\mathrm{A}$ allele frequency in both Asian and Caucasian populations is approximately $25 \%$ on average $[7,8]$ and is $8 \%$ in African-Americans [7]. The allele frequency was $31 \%$ in the Kazakh population, which corresponds with the frequencies in Asian and Caucasian populations $(\mathrm{p}=0.25)$. The allele frequency in the Russian population was 0.24 , which is near to that of the Japanese population $(\mathrm{p}=0.38)$.

\section{GGCX gene}

A mutant version of the GGCX gene (rs11676382) occurs at a frequency of $10 \%$ in Caucasian populations and nearly never occurs in the Asian and African-American populations [21]. The allele frequency in Kazakh population was $4 \%$, which is between the Caucasoid and Asian populations.

The allele frequency in the Russian population was $8 \%$, which corresponds with the Caucasian population $(\mathrm{p}=0.77)$.

\section{CYP2D6 gene}

Ethnic differences in the frequencies of polymorphisms of this gene are very high. The $C Y P 2 D 6^{*} 3$ and $C Y P 2 D 6^{*} 4$ alleles are almost never found in Asian and African populations. CYP2D6*3 occurs at a frequency of 0.01-0.02 and CYP2D $6^{*} 4$ at a frequency of 0.07-0.20 in the Caucasian population [22-24].

The frequency of $C Y P 2 D 6^{*} 4(0.07)$ in the Kazakh population is significantly different from that of the Caucasian population $(\mathrm{p}=0.00)$ and corresponds to the frequencies in Asian populations. At the same time, the frequency of $C Y P 2 D 6^{*} 3$ is closer to that of Caucasian populations $(\mathrm{p}=0.93)$.

In the studied Russian population, the frequency of $C Y P 2 D 6^{*} 3$ $(0.15)$ is higher than in all analysed populations and does not correspond well with the literature data $(\mathrm{p}=0.00)$. The frequencies of CYP2D6*4 (0.22) found in our study are similar to those of similar populations reported in the literature $(\mathrm{p}=0.85)$.

\section{CYP1A2 gene}

The $C Y P 1 A 2^{\star} 1 F$ allelic polymorphism frequency varies widely between populations, ranging from $22 \%$ in the Caucasian population to $61 \%$ in the Japanese population. The average frequency of the CYP $1 A 2^{*} 1 F$ allele is $31 \%$ in the Caucasian population, $37 \%$ in the Asian population, and reaches $46 \%$ in the African-American population $[20,25]$. In the Kazakh population, the frequency was $35 \%$, which is between the Caucasian and Asian populations.

The allele frequency in the Russian population was $31 \%$, which is typical for Caucasian populations $(\mathrm{p}=0.14)$. The allele frequency of the studied Kazakh and Russian population was nearly the same $(\mathrm{p}=0.17)$.

\section{Conclusions}

The Kazakh population exhibits allele frequencies at an intermediate level between Caucasian and Asian populations in nearly all of the studied gene allele variants. This distribution of frequencies can be explained by recent studies that have suggested that the Kazakh population was formed by the mixing of Asian and Caucasoid populations [14]. Currently, individuals exhibit distinctive Asian and/ or Caucasoid traits, depending on the region of Kazakhstan. Based on our data, we can conclude that further pharmacogenetic studies are required.

\section{Availability of Supporting Data}

The datasets used in this article are included here.

\section{Competing Interests}

The authors declare that they have no competing interests.

\section{Authors' Contributions}

I.A.N. extracted DNA, performed SNP genotyping, summarised genotyping data, analysed data, carried out statistical analysis and drafted the manuscript. R.A.A. extracted DNA and performed SNP genotyping. V.E.N. helped edit the manuscript and developed the SNP typing methods (RT-PCR). S.N.S. carried out the statistical analysis. B.L.A. performed SNP genotyping for Russian populations. R.E.M. and F.M.L. helped edit the manuscript and made suggestions on study design. All authors read and approved the final manuscript.

\section{Acknowledgement}

This work was supported by grant No. 1.04.01 from the Ministry of Education and Science of the Republic of Kazakhstan.

\section{References}

1. Sychev DA (2005) Clinical pharmacogenetic as a way to personalized medicine: Are expectations justified? Clinical Pharmacology and Therapy 14: 77-83.

2. The Pharmacogenomics Knowledge Base.

3. Limdi NA, McGwin G, Goldstein JA, Beasley TM, Arnett DK, et al. (2008) Influence of $\mathrm{CYP} 2 \mathrm{C} 9$ and $\mathrm{VKORC1} 1173 \mathrm{C} / \mathrm{T}$ genotype on the risk of hemorrhagic complications in African-American and European-American patients on warfarin. Clin Pharmacol Ther 83: 312-321.

4. Wang TL, Li HL, Tjong WY, Chen QS, Wu GS, et al. (2008) Genetic factors contribute to patient-specific warfarin dose for Han Chinese. Clin Chim Acta 396: 76-79.

5. Takahashi H, Wilkinson GR, Nutescu EA, Morita T, Ritchie MD, et al. (2006) Different contributions of polymorphisms in VKORC1 and CYP2C9 to intraand inter-population differences in maintenance dose of warfarin in Japanese, Caucasians and African-Americans. Pharmacogenet Genomics 16: 101-110.

6. Rieder MJ, Reiner AP, Gage BF, Nickerson DA, Eby CS, et al. (2005) Effect of VKORC1 haplotypes on transcriptional regulation and warfarin dose. $\mathrm{N}$ Engl J Med 352: 2285-2293.

7. Singh O, Sandanaraj E, Subramanian K, Lee LH, Chowbay B (2011) Influence of CYP4F2 rs2108622 (V433M) on warfarin dose requirement in Asian patients. Drug Metab Pharmacokinet 26: 130-136.

8. Liang R, Li L, Li C, Gao Y, Liu W, et al. (2012) Impact of CYP2C9*3 VKORC1-1639, CYP4F2rs2108622 genetic polymorphism and clinical factors on warfarin maintenance dose in Han-Chinese patients. J Thromb Thrombolysis 34: $120-125$

9. Stec DE, Roman RJ, Flasch A, Rieder MJ (2007) Functional polymorphism in human CYP4F2 decreases 20-HETE production. Physiol Genomics 30: 74-81.

10. Rieder MJ, Reiner AP, Rettie AE (2007) Gamma-glutamyl carboxylase (GGCX) tagSNPs have limited utility for predicting warfarin maintenance dose. J Thromb Haemost 5: 2227-2234

11. Jaquenoud Sirot E, Knezevic B, Morena GP, Harenberg S, Oneda B, et al. (2009) ABCB1 and cytochrome P450 polymorphisms: clinical pharmacogenetics of clozapine. J Clin Psychopharmacol 29: 319-326.

12. Zhou SF, Yang LP, Zhou ZW, Liu YH, Chan E (2009) Insights into the substrate specificity, inhibitors, regulation, and polymorphisms and the clinical impact of human cytochrome P450 1A2. AAPS J 11: 481-494.

13. Agency of statistics of the Republic of Kazakhstan

14. Iskakova MK (2012) Kazakh's tamga. Saryarka Press, Astana. 
Citation: Iskakova AN, Romanova Voronina AA, Voronina EN, Sikhayeva NS, Belozerceva AB, et al. (2014) Allele Frequency and Genotype Distribution of 9 SNPs in the Kazakh Population. J Pharmacogenomics Pharmacoproteomics 5: 129. doi:10.4172/2153-0645.1000129

15. Salting-out extraction method.

16. Phenol-chloroform extraction method.

17. Wang SM, Zhu AP, Li D, Wang Z, Zhang P, et al. (2009) Frequencies of genotypes and alleles of the functional SNPs in CYP2C19 and CYP2E1 in mainland Chinese Kazakh, Uygur and Han populations. J Hum Genet 54: 372 375 .

18. Magalon H, Patin E, Austerlitz F, Hegay T, Aldashev A, et al. (2008) Population genetic diversity of the NAT2 gene supports a role of acetylation in human adaptation to farming in Central Asia. Eur J Hum Genet 16: 243-251.

19. Tarlykov PV, Zholdybayeva EV, Akilzhanova AR, Nurkina ZM, Sabitov ZM, et al. (2013) Mitochondrial and Y-chromosomal profile of the Kazakh population from East Kazakhstan. Croat Med J 54: 17-24.

20. Marie-Genica Consortium on Genetic Susceptibility for Menopausal Hormone Therapy Related Breast Cancer Risk1 (2010) Genetic polymorphisms in phase I and phase II enzymes and breast cancer risk associated with menopausal hormone therapy in postmenopausal women. Breast Cancer Res Treat 119 $463-474$

21. King CR, Deych E, Milligan P, Eby C, Lenzini P, et al. (2010) Gamma-glutamyl carboxylase and its influence on warfarin dose. Thromb Haemost 104: 750754.

22. Sachse C, Brockmöller J, Bauer S, Roots I (1997) Cytochrome P450 2D6 variants in a Caucasian population: allele frequencies and phenotypic consequences. Am J Hum Genet 60: 284-295.

23. Brown MA, Edwards S, Hoyle E, Campbell S, Laval S, et al. (2000) Polymorphisms of the CYP2D6 gene increase susceptibility to ankylosing spondylitis. Hum Mol Genet 9: 1563-1566.

24. Kubota T, Yamaura Y, Ohkawa N, Hara H, Chiba K (2000) Frequencies of CYP2D6 mutant alleles in a normal Japanese population and metabolic activity of dextromethorphan O-demethylation in different CYP2D6 genotypes. $\mathrm{Br} \mathrm{J}$ Clin Pharmacol 50: 31-34.

25. Hamdy SI, Hiratsuka M, Narahara K, Endo N, El-Enany M, et al. (2003) Genotyping of four genetic polymorphisms in the CYP1A2 gene in the Egyptian population. Br J Clin Pharmacol 55: 321-324

26. Ingelman-Sundberg M, Sim SC, GomezA, Rodriguez-Antona C (2007) Influence of cytochrome P450 polymorphisms on drug therapies: pharmacogenetic, pharmacoepigenetic and clinical aspects. Pharmacol Ther 116: 496-526.

27. Nebert DW, McKinnon RA (1994) Cytochrome P450: evolution and functional diversity. Prog Liver Dis 12: 63-97.

28. Meyer UA (1994) Pharmacogenetics: the slow, the rapid, and the ultrarapid. Proc Natl Acad Sci U S A 91: 1983-1984.

29. Limdi NA, Beasley TM, Crowley MR, Goldstein JA, Rieder MJ, et al. (2008) VKORC1 polymorphisms, haplotypes and haplotype groups on warfarin dose among African-Americans and European-Americans. Pharmacogenomics 9: 1445-1458.

30. Watson MA, Stewart RK, Smith GBJ, Massey TE, Bell DA (1998) Human glutathione S-transferase $\mathrm{P} 1$ polymorphisms: relationship to lung tissue enzyme activity and population frequency distribution. Carcinogenesis 19: 275280

31. Rathore SS, Agarwal SK, Pande S, Mittal T, Mittal B (2010) Frequencies of VKORC1 $-1639 \mathrm{G}>\mathrm{A}, \mathrm{CYP} 2 \mathrm{C}{ }^{*} 2$ and CYP2C9*3 genetic variants in the Northern Indian population. Biosci Trends 4: 333-337.

32. Munshi A, Sharma V, Kaul S, Al-Hazzani A, Alshatwi AA, et al. (2012) Association of 1347 G/A cytochrome P450 4F2 (CYP4F2) gene variant with hypertension and stroke. Mol Biol Rep 39: 1677-1682.

33. Bravo-Villalta HV, Yamamoto K, Nakamura K, Bayá A, Okada Y, et al. (2005) Genetic polymorphism of CYP2C9 and CYP2C19 in a Bolivian population: an investigative and comparative study. Eur J Clin Pharmacol 61: 179-184.
34. Mushiroda T, Ohnishi Y, Saito S, Takahashi A, KikuchiY, et al. (2006) Association of VKORC1 and CYP2C9 polymorphisms with warfarin dose requirements in Japanese patients. J Hum Genet 51: 249-253.

35. Rusdiana T, Araki T, Nakamura T, Subarnas A, Yamamoto K (2013) Responsiveness to low-dose warfarin associated with genetic variants of VKORC, CYP2C9, CYP2C19, and CYP4F2 in an Indonesian population. Eur J Clin Pharmacol 69: 395-405.

36. Sayed SK, Imam HMK (2012) Study of the Association of CYP2D6*4 Polymorphism with the Susceptibility of HCV- Related Liver Cirrhosis and Liver Cancer. Life Science Journal 9:1571-1577.

37. Qumsieh RY, Ali BR, Abdulrazzaq YM, Osman O, Akawi NA, et al. (2011) Identification of new alleles and the determination of alleles and genotypes frequencies at the CYP2D6 gene in Emiratis. PLoS One 6: e28943.

38. Menoyo A, del Rio E, Baiget M (2006) Characterization of variant alleles of cytochrome CYP2D6 in a Spanish population. Cell Biochem Funct 24: 381-385.

39. Gaikovitch EA, Cascorbi I, Mrozikiewicz PM, Brockmöller J, Frötschl R, et al (2003) Polymorphisms of drug-metabolizing enzymes CYP2C9, CYP2C19, CYP2D6, CYP1A, NAT2 and of P-glycoprotein in a Russian population. Eur J Clin Pharmacol 59: 303-312.

40. Ahmadishina LZ (2007) Monooxygenase enzyme gene polymorphism and the antioxidant defense system in patients with chronic diseases of the respiratory system in the Republic of Bashkortostan, Abstract.

41. Santos PC, Dinardo CL, Schettert IT, Soares RA, Kawabata-Yoshihara L, et al. (2013) CYP2C9 and VKORC1 polymorphisms influence warfarin dose variability in patients on long-term anticoagulation. Eur J Clin Pharmacol 69: 789-797.

42. Branco CC, Pereirinha T, Cabral R, Pacheco PR, Mota-Vieira L (2009) Thrombotic genetic risk factors and warfarin pharmacogenetic variants in São Miguel's healthy population (Azores). Thromb J 7: 9.

43. Roco A, Quiñones L, Agúndez JAG, García-Martín E, Squicciarini V, et al. (2012) Frequencies of 23 functionally significant variant alleles related with metabolism of antineoplastic drugs in the Chilean population: comparison with Caucasian and Asian populations. Front Genet 3: 229.

44. Zainuddin Z, Teh LK, Suhaimi AW, Ismail R (2006) Malaysian Indians are genetically similar to Caucasians: CYP2C9 polymorphism. J Clin Pharm Ther 31: 187-191.

45. Cornelis MC, El-Sohemy A, Kabagambe EK, Campos H (2006) Coffee CYP1A2 genotype, and risk of myocardial infarction. JAMA 295: 1135-1141.

46. Suarez-Kurtz G (2005) Pharmacogenomics in admixed populations. Trends Pharmacol Sci 26: 196-201.

47. Sistonen J, Sajantila A, Lao O, Corander J, Barbujani G, et al. (2007) CYP2D6 worldwide genetic variation shows high frequency of altered activity variants and no continental structure. Pharmacogenet Genomics 17: 93-101.

48. Solus JF, Arietta BJ, Harris JR, Sexton DP, Steward JQ, et al. (2004) Genetic variation in eleven phase I drug metabolism genes in an ethnically diverse population. Pharmacogenomics 5: 895-931. 